\title{
Study of the hydromineral regulation of Typhlonectes compressicauda according to the seasonal variation
}

\author{
Mohammad Yousef $^{1}$, Elara N. Moudilou ${ }^{1}$, Hafsa Djoudad-Kadji ${ }^{2}$, Jean-Marie Exbrayat ${ }^{1}$ \\ ${ }^{1}$ University of Lyon, UMRS 449, Laboratory of General Biology, Lyon Catholic University; \\ Laboratory of Reproduction and Comparative Development, Lyon, France \\ ${ }^{2}$ Laboratoire de Zoologie Appliquée et d'Ecophysiologie Animale, Faculté des Sciences \\ de la Nature et de la Vie, Université de Bejaia, Algérie
}

\begin{abstract}
Introduction. Typhlonectes compressicauda is a viviparous gymnophionan amphibian living in tropical areas of South America. This lengthened amphibian is submitted to seasonal variations characterized by the rainy season (from January to June) and the dry season (from July to December). The mineral homeostasis in amphibians is partly ensured by the neurohormones arginine-vasotocin (AVT), and mesotocin (MST). These two hormones were localized in the hypothalamus, and their receptors, mesotocin receptors (MTR) and vasotocin receptors $\left(\mathrm{VTR}_{2}\right)$ in the kidney. The aim of the study was to better understand the physiology of the hydromineral regulation of the studied species.

Material and methods. The specimens of T. compressicauda male and female adult were divided into 6 groups: males in the rainy season, males in the dry season, females pregnant in the rainy season, females pregnant in the dry season, females not pregnant in the rainy season, females not pregnant in the dry season. We studied the expression of hormones (AVT, MST) and their receptors $\left(\mathrm{MTR}, \mathrm{VTR}_{2}\right)$ in the hypothalamus and the kidney, respectively, by immunohistochemical and histological techniques. We also studied the expression of aquaporin-2 $\left(\mathrm{AQP}_{2}\right)$, a water-channel protein in the kidney.

Results. We found that the MST (diuretic hormone) and its receptor were more intensively expressed during the rainy season, whereas the period of maximal AVT (anti-diuretic hormone) and $\mathrm{VTR}_{2}$ expression was the dry season. A quantitative analysis showed significant differences in the number of labeled cells in the hypothalamus depending on the seasonal variation. The expression of $\mathrm{AQP}_{2}$ was observed in renal tubules during both seasons with an increased intensity during the dry season.

Conclusion. The expression of the MST/AVT in brain, their receptors MTRs/VTR 2 , and AQP in kidney changed in T. compressicauda according to the seasonal variations. A direct relationship between the seasonal cycle and reproduction cycle was demonstrated in this species. (Folia Histochemica et Cytobiologica 2018, Vol. 56, No. 3, 172-183)
\end{abstract}

Key words: Amphibian, gymnophiona; Typhlonectes compressicauda; mesotocin; vasotocin; vasotocin receptors; aquaporin; IHC

Correspondence address: J.-M. Exbrayat

UMRS 449, General Biology - Reproduction and

comparative development, Lyon Catholic University, UDL;

Ecole Pratique des Hautes Etudes, PSL, 10 place des Archives, F-69288 Lyon Cedex 02, France

phone: +33478325036

e-mail: jmexbrayat@univ-catholyon.fr

\section{Introduction}

Gymnophiona or caecilians are limbless, lengthened burrowing amphibians that live in tropical countries [1-3]. Most organs are elongated in caecilians body, with a variable size. Species can be oviparous, viviparous [4-6] or they can develop directly [7, 8]. T. compressicauda is an aquatic species, with ringed body and without tail $[9,10]$. The adult size is comprised 


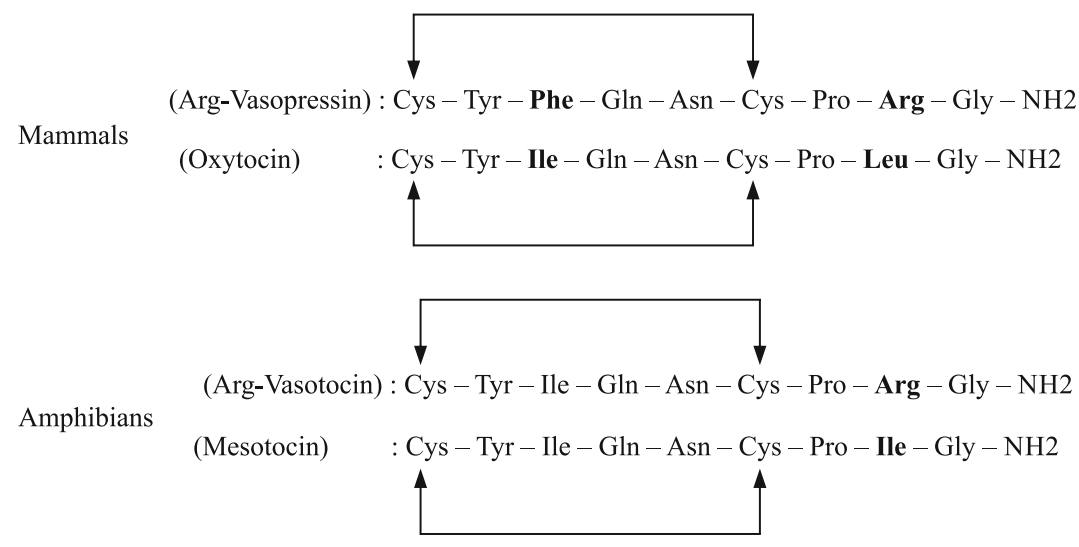

Figure 1. Structure of the oxytocine, arginine vasopressin, mesotocin and arginine vasotocin. This picture shows nine amino acids and a disulfide bridge between two cysteines in position 1 and 6 (from Yousef M, unpublished PhD thesis, Lyon University, 2016)

between $30-60 \mathrm{~cm}$, and diameter between $2-2.5 \mathrm{~cm}$. T. compressicauda is a viviparous species, with internal fertilization, and males possess an intromission organ, the phallodeum.

The reproductive cycles are narrowly submitted to the seasonal variations. These variations are characterized by the rainy season (from January to June), distinguished by high water level and swamped savannas, and the dry season (from July to December), characterized by a fall in water level and animals living in the mud $[2,10]$. The male cycle is yearly, and breeding occurs during the rainy season. A fast gametogenesis is observed in August, followed by a resting period during the dry season. In October, when the water level is lowest, spermatic secretions start, and the animal becomes ready to breed in the rainy season. The fertilization occurs between January and April. In females, the breeding cycle is biennial with ovulation at the beginning of the first year, in January-February. Then, fertilized females remain pregnant during six months and give birth to newborn looking like small adults, in the dry season, when $T$. compressicauda live buried in the muddy ground. This burying period could represent a protection for the newborn against the predators. In October, the reproduction preparation starts in genital tract. But, in next January, at theoretical time of ovulation, there is no vitellogenic oocyte, genital tract regresses and female remains quiescent till the end of cycle $[6,11]$.

The hydromineral regulation in vertebrates is controlled by neurohormones, such as arginine vasopressin (AVP), oxytocin (OT), arginine vasotocin (AVT), mesotocin (MST) and isotocin (IST). These hormones exist in vertebrates in different ways: the AVT and MST are observed in lungfish, amphibians, reptiles, and birds, whereas AVP and OT are observed in mammals [12-16]. Structurally, these hormones are nonapeptides with a disulfide bridge between two cysteines in position 1 and 6 , and they differ only by three amino acids. MST and AVT differ only by one amino acid in position 8, and OT and AVP differ by two amino acids, located at positions 3 and 8 (Fig. 1). These different amino acids play a determining role in the recognition of peptides by their receptors [17]. These neurohormones are synthesized in the anterior hypothalamus, and then stocked in neurohypophysis.

AVT and MST have the equivalent functions to AVP and OT in mammals. They are implicated in hydromineral regulation and other endocrine functions [12, 18-20]. The MST is a diuretic agent, acting by increasing the glomerular filtration or by antagonizing the antidiuretic actions of vasotocin. AVT acts as an antidiuretic agent, increasing the permeability of the renal collecting duct system, allowing the reabsorption of water [21]. Aquaporins or water channels are membrane proteins regulated by vasopressin/vasotocin which increase the membrane permeability to water by forming pores selective to water in cell membrane $[22,23]$.

In amphibians, the distribution of MST and AVT is wide in the brain, and it was demonstrated that these peptides performed important functions in water balance, social and reproductive behaviors, biosynthesis of neurosteroids [24-27]. The MST and AVT actions are mediated through their receptors, belonging to the G protein-coupled receptor (GPCR) superfamily. In Amphibians, two receptors for AVT (AVTRs) and one receptor for MST (MTR) have been described $[28,29]$. The aquaporins play a fundamental role in the resorption/absorption of water in amphibians. Some studies reported that the movement of water through the epithelium was controlled by AVT [30]. 
Table 1. Gender and seasonal distribution of the studied T. compressicauda

\begin{tabular}{|c|c|c|c|c|c|}
\hline \multicolumn{2}{|c|}{ Males } & \multicolumn{2}{c|}{ Females pregnant } & \multicolumn{2}{c|}{ Females not pregnant } \\
\hline $\begin{array}{c}\text { Rainy period } \\
\text { January-June }\end{array}$ & $\begin{array}{c}\text { Dry period } \\
\text { July-December }\end{array}$ & $\begin{array}{c}\text { Rainy period } \\
\text { January-June }\end{array}$ & $\begin{array}{c}\text { Dry period } \\
\text { July-December }\end{array}$ & $\begin{array}{c}\text { Rainy period } \\
\text { January-June }\end{array}$ & $\begin{array}{c}\text { Dry period } \\
\text { July-December }\end{array}$ \\
\hline 4 & 4 & 4 & 4 & 4 & 4 \\
\hline
\end{tabular}

In addition to the kidneys, the amphibians developed other organs specialized in osmoregulatation. In order to assure the adaptation with the environment: the ventral pelvic skin absorbs the water from the external environment; the bladder stores the water or reabsorbs it according to the needs [30-33]. In frogs, three types of AVT-dependent AQPs can be classified such as osmoregulatory organs: AQP-type kidney, AQP-type pelvic skin, and AQP-type urinary bladder [34]. The studies have shown the presence of three AVT-dependent AQPs in Japanese tree frog (Hyla japonica): AQP2, called AQP-h2k, and two subtypes of AQPa2, AQP-h2 and AQP-h3 [35-37]. AQP-h2k was observed in the kidney and it seemed acceptable that its function was similar to that of AQP2 in mammal's kidney. It facilitates the reabsorption of water at the collector channel in response to antidiuretic hormone [37, 38].

The adult kidney of $T$. compressicauda has been studied in the context of a comparative study by Wake [39]. The organization of $T$. compressicauda kidneys was precisely described in several studies [40-42]. They form two tight elongated bands, extending from the end of the heart to the cloaca, with the presence of inter-renal glands located between the kidneys. Histological variations of nephrons were observed according to the seasonal variation. The width of Bowman's space and sinusoids were wider during the rainy season compared with the dry season (personal data).

Several studies were already carried out in order to understand the amphibian's nervous system morphology [43, 44]. Anterio-posteriorly oriented Typhlonectes' brain is composed of telencephalon, diencephalon, mesencephalon, and rhombencephalon $[45,46]$. The pineal gland is a small structure, in the form of pea coming from the diencephalon [44]. The anterior pituitary is flattened and contains several cellular types [47, 48]. Gymnophionan brain shares common characteristics with other amphibians, but it has some specific features: prominent form of the forebrain, a pronounced rhombo-mesencephalic flexion and atrophied optic lobes and nerves. To compensate the optic weakness, Typhlonectes has sensory organs such as tentacles [49].

During the rainy season, $T$. compressicauda lives in aquatic environment, whereas in the dry season, it lives in a muddy terrestrial environment, when water took off the savannas. Therefore, it is submitted to external factors causing strong variations of the osmotic pressure, which must be regulated in order to preserve its physiological constants. The aim of the present work was to investigate AVT/MST osmoregulatory system of $T$. compressicauda, at the hypothalamic level, and the presence of $\mathrm{VTR}_{2} / \mathrm{AQP}_{2}$ in kidneys according to the seasonal alternations by the immunocytochemical method.

\section{Materials and methods}

The study was performed on a T. compressicauda collection of male and female adult specimens. The animals were captured in Kaw (1979-1983), a village situated $80 \mathrm{~km}$ south from Cayenne in French Guiana. Twenty-four individuals were selected and distributed into 4 categories according to sex and capture period (Table 1).

Tissue sampling. After dissecting fixed animals, kidneys and brains were dehydrated and embedded in paraffin. Transversal sections ( $5 \mu \mathrm{m}$ thick) were prepared for the study. A topographical staining with cresyl violet allowed realizing the complete cartography of the T. compressicauda brain in order to specify the location of the hypothalamus.

Immunohistochemistry. The detection of the MST/AVT in brains and $\mathrm{VTR}_{2} / \mathrm{AQP}_{2}$ in kidneys were performed using avidin-biotin amplification method. The sections were dewaxed and washed with phosphate-buffered saline (PBS). Then, the blocking of endogenous peroxidase activity was carried out by incubating the sections for $30 \mathrm{~min}$ in a $3 \%$ $\mathrm{H}_{2} \mathrm{O}_{2}$ solution. Endogenous biotins were blocked with the avidin/biotin blocking kit (Vector Laboratories, Burlingame, CA, USA) with $15 \mathrm{~min}$ for each solution. Then, the sections were incubated with a bovine serum albumin (BSA) 2\% blocking solution for AVT/MST and with normal horse serum for MTRs/VTR $/ \mathrm{AQP}_{2}$ (Vectastain ${ }^{\circledast}$ Universal Quick Kit, Vector Laboratories) during $2 \mathrm{~h}$. This step was followed by $2 \mathrm{~h}$ incubation with primary antibodies: anti-oxytocin polyclonal primary antibody (AB911, Millipore Temacula, CA, USA) for MST, anti-vasopressin polyclonal primary antibody (AB1565, Millipore) for AVT, anti-AVP Receptor V2 (P-20, Santa Cruz, Dallas, TX, USA) for VTR 2 , and anti-AQP2 polyclonal primary antibody (C-17, Santa Cruz) for $\mathrm{AQP}_{2}$. After washing, slides were treated according to 


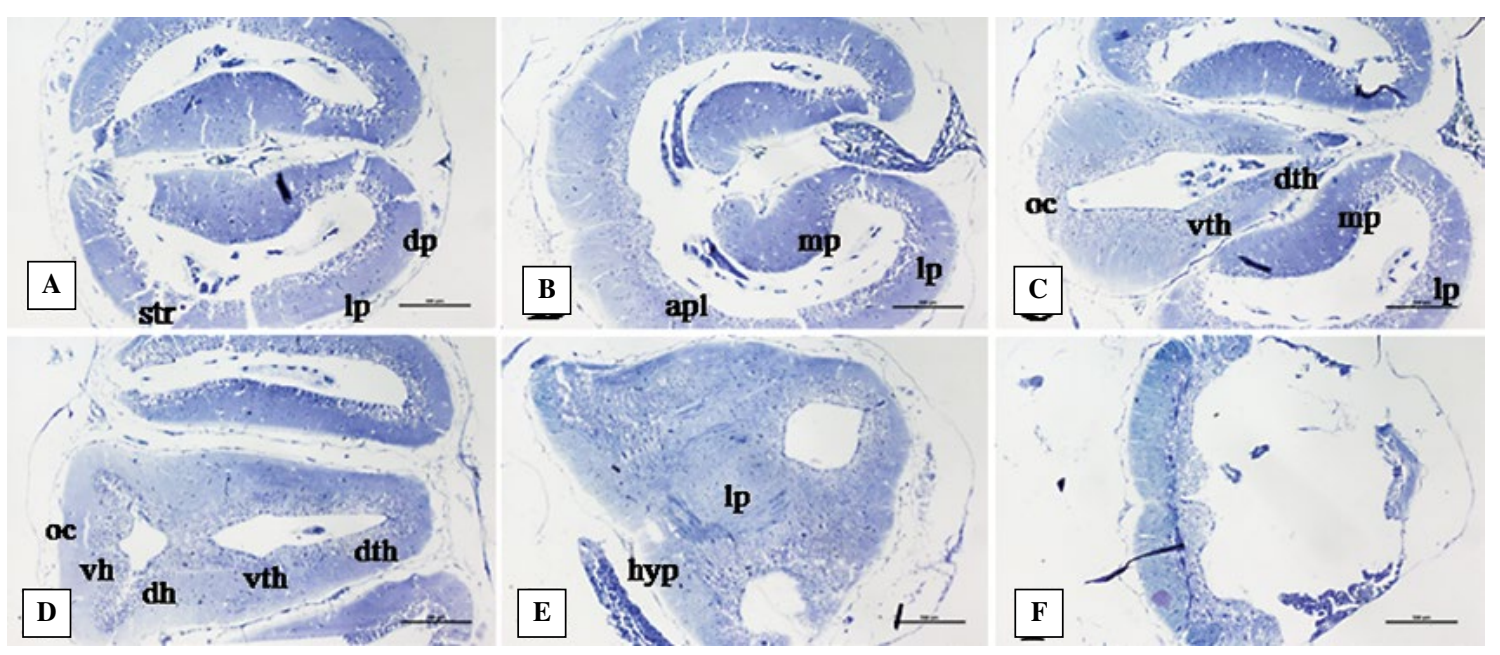

Figure 2. Transverse sections of T. compressicauda brain stained with cresyl violet. Microphotographs show different parts of brain (male, rainy season). A. Telencephalon. B. Posterior telencephalon. C and D. Caudal telencephalon and diencephalon. E. Mesencephalon. F. Rhombencephalon. Abbreviations: apl — amygdale; dh — dorsal hypothalamus ; dp — dorsal pallium; $\mathrm{dth}$ - dorsal thalamus; hyp — hypophyse; Inf — infundibulum; lp — lateral pallium; $\mathrm{mp}$ - medial pallium; oc — optique chiasma; str — stratum; vh — ventral hypothalamus; vth — ventral thalamus. Scale bar: $200 \mu \mathrm{m}$.

the manufacturer's instructions. Staining was completed with ImmPACT Nova RED and counterstained for $30 \mathrm{~s}$ to $1 \mathrm{~min}$ with hematoxylin QS (Vector Laboratories). Finally, sections were dehydrated and mounted in a hydrophobic medium.

For each experiment, a negative control by omission of primary antibody was carried out. In addition, to determine the specificity of the antibody used (antibody directed to human protein on amphibian tissue), a blocking peptide test was performed.

Histomorphometry. A quantitative study was made on 4 animals of each category $(n=24)$ by counting the labeled cells in the hypothalamus. For each animal, four slides were counted every $10 \mu \mathrm{m}$. They were chosen in the most developed part of the hypothalamus and observed at $1000 \times$ magnification. The photographs were obtained from a microscope Elipse E400 Nikon connected with a camera DS-5Mc piloted by NIS-ELEMENTS BR 3.10 program (Nikon). This program was used to determine the organ area on each slide by drawing a border outline and to point each positive neuron.

Statistical analysis. For the data analysis, principal component analysis (PCA) followed with a Spearman test was performed with a risk of error fixed at 5\%. All analyses were performed with Statistica 5.5 (Statsoft, Tulsa, OK, USA).

\section{Results}

\section{Cartography of the T. compressicauda brain}

The complete cartography of the brain was performed for each individual studied. Staining with cresyl violet allowed to distinctly specify the different parts of the brain (Fig. 2) and, consequently, to identify the slides containing the hypothalamus. The hypothalamus is located in the diencephalon, and it is the main area of AVT/MST production.

Three types of cells have been determined in the hypothalamus: magnocellular cells (the most voluminous), intermediate cells (the least voluminous) and ependymal cells. The both optic nerves were very poorly developed; the optic chiasma was small and persisted under the diencephalon. The cell juxtapositions or coupling were also observed allowing the synchronization of the cellular activity (Fig. 3).

\section{Location of the MST/AVT immunopositive cells}

Immunolabeling of hormones (AVT/MST) was performed under the same conditions for every individual brain on the sections that contain the hypothalamic region. The examination of the sections treated with polyclonal primary antibody (anti-oxytocin and anti-vasopressin) allowed the detection of the MST/AVT in T. compressicauda brains. The immunoreactivity of the MST (diuretic hormone) and AVT (antidiuretic hormone) was observed in the hypothalamus during the rainy season and the dry season in all categories (males and pregnant and non-pregnant females). An obvious cytoplasmic staining of the MST/AVT was observed during both the dry and rainy seasons in males and pregnant and non-pregnant females. The immunoreactivity was intensely expressed on the magnocellular cells, 


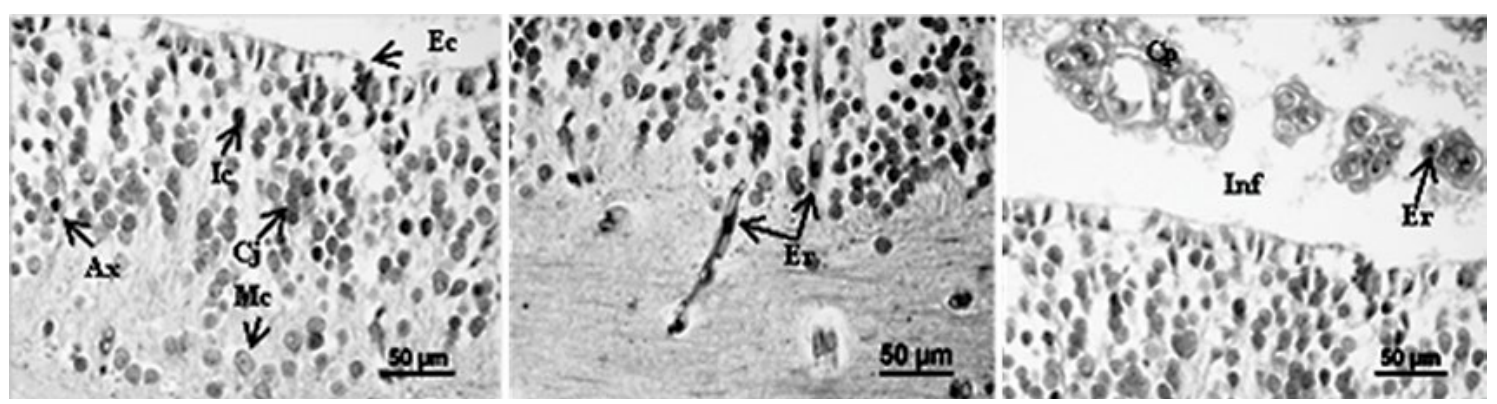

Figure 3. Hypothalamic region of $T$. compressicauda brain stained with cresyl violet (male, rainy season). Abbreviations: $\mathrm{Ax}$ - axone; Cp — choroid plexus; Ec — ependymal cells; Er — erythrocyte; Ic — intermediate cells; Inf — infundibulum; Mc - magnocellular cells. Scale bar: $50 \mu \mathrm{m}$.

their axons and the intermediate cells (Fig. 4A, B). On these microphotographs, we could see the nuclei red labeled (n.m), in addition on each slide, internal negative controls were easily identified stained blue by hematoxylin as internal controls (n.n.m). The slides with omission of the primary antibody to each section were negative: the nuclei were blue stained and cytoplasm were not stained (Fig. 4).

After visualization of the hormones, the effects of seasonal alternations on the immunostaining of each neurohormone were studied. The results showed that the hormones labeled presented a different intensity of the immunoreactivity according to the season.

MST immunostaining was more intense during the rainy season compared with the dry season (Fig. 4C vs 4D) whereas AVT immunostaining was more intense during the dry season than during the rainy season (Fig. 4E vs 4F). After the hormones being localized, a comparison was performed according to the seasons: some remarkable and important differences in staining intensity of these hormones were observed. During the dry season, AVT label was higher than MST one. On the contrary, during the rainy season; the MST label was stronger than the AVT one.

\section{Quantification of the MST and AVT immunoreactive cells in hypothalamus}

To confirm the results, a quantitative study with statistical analysis was performed on 4 animals of each category $(n=24)$ according to seasonal variations. For each animal, we determined a density, i.e. the number of immunoreactive (Ir) cells per $\mu \mathrm{m}^{2}$ of hypothalamus. The graphs show variations in the number of labeled cells between the two hormones depending on the season (Fig. 5). For the AVT (Fig. 5A), the anti-diuretic hormone, which action is less essential during the rainy season, we could observe approximatively $1 \times 10^{-3}$ AVT-Ir neurons per $\mu \mathrm{m}^{2}$ (from $0.76 \pm 0.16 \times 10^{-3}$ in non-pregnant females to
$1.03 \pm 0.15 \times 10^{-3}$ per $\mu \mathrm{m}^{2}$ in males). While, during its period of action (dry season), the density increased to approximately $1.5 \times 10^{-3}$ AVT-Ir cells per $\mu \mathrm{m}^{2}$ (from $1.36 \pm 0.07 \times 10^{-3}$ in pregnant females to $1.61 \pm 0.4 \times$ $\times 10^{-3}$ positives cells per $\mu \mathrm{m}^{2}$ in males. For MST (Fig. 5B), a diuretic hormone, the number of MST-Ir cells is higher during the rainy season (from $1.37 \pm 0.07 \times$ $\times 10^{-3}$ in males to $1.52 \pm 0.25 \times 10^{-3}$ in non-pregnant females) compared with the dry season (from $0.83 \pm$ $\pm 0.23 \times 10^{-3}$ in pregnant females to $1.09 \pm 0.11 \times$ $\times 10^{-3}$ in non-pregnant females). Statistical analysis corroborated the qualitative season-related observations. The number of AVT-positive cells was higher during the dry season, whereas MST-positive cells were more prevalent during the rainy season (Fig. 5D) (Fig. 5C).

\section{Blocking peptide test}

The results of blocking peptide test for AVT/MST/ /VTRs and $\mathrm{AQP}_{2}$ resembled highly the negative control and showed well-saturated peptides blocking the activity of antibodies. These results showed cross-reactions between the antibodies directed against human proteins and antibodies against the proteins of the species studied, and therefore one can assume the antibody is specific.

\section{Location of the VTR ${ }_{2}$ in kidney}

The localization of AVT receptors involved in the reabsorption of water $\left(\mathrm{VTR}_{2}\right)$ was also performed by an immunohistochemical study in T. compressicauda kidney. The visualization was performed on four slides per brain from individuals belonging to each group. The results obtained showed that the $\mathrm{VTR}_{2}$ was well detected in the kidney (males, pregnant and non-pregnant females) during both seasons.

A cytoplasmic staining was well observed in different renal tubules (proximal, distal, collector, and neck segment). During the dry and rainy season in 


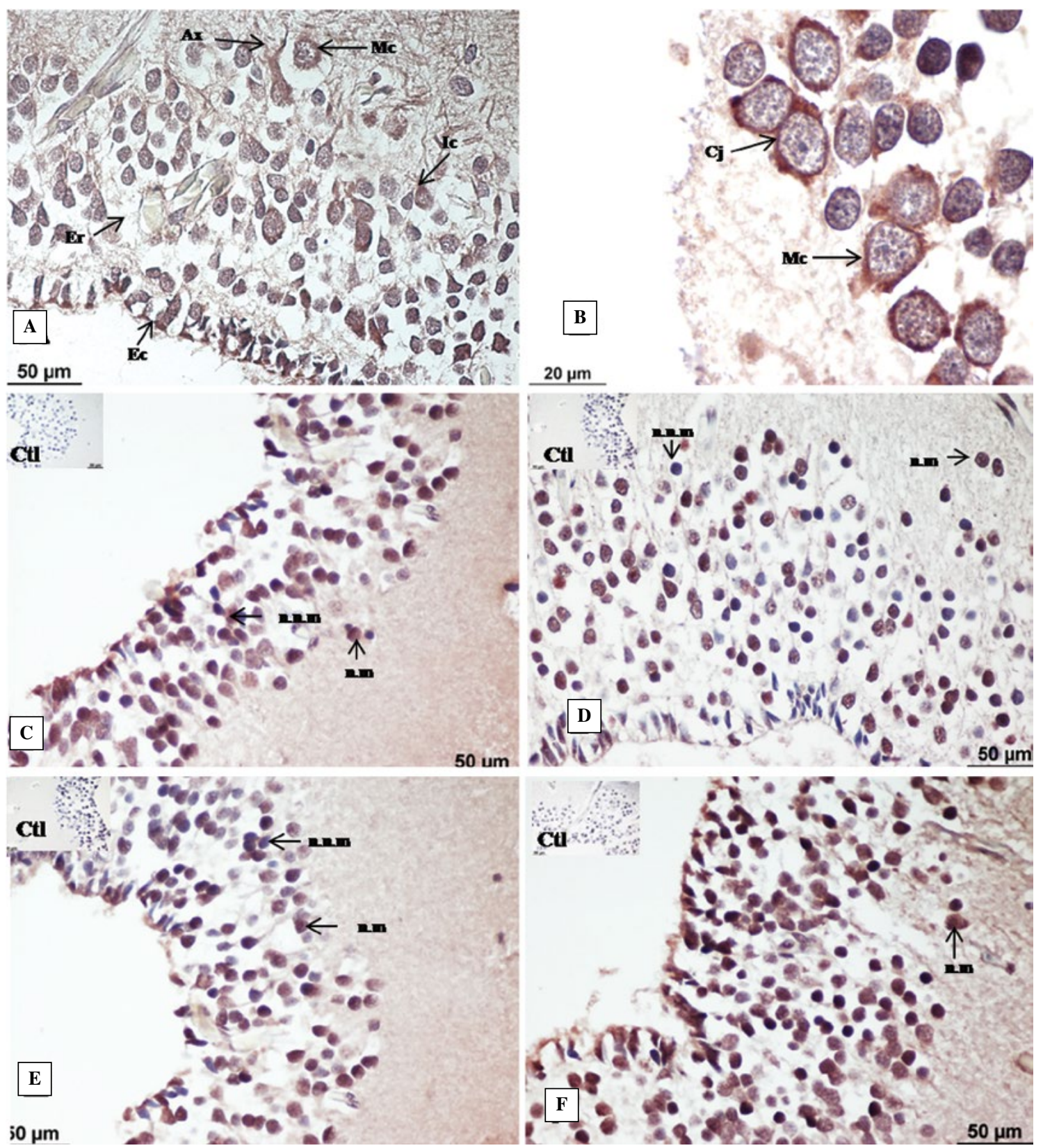

Figure 4. Variations in the expression of MST and AVT in T. compressicauda hypothalamic area according to the seasonal cycle. A. Repartition of hypothalamic cells marked with AVT or MST (here: MST cells in male, rainy season). B. Hypothalamic cells containing MST: details of the immunostaining (male, rainy season). C. MST in male, rainy season. D. MST in male, dry season. E. AVT in male, rainy season. F. AVT in male, dry season. MST and AVT were observed in all groups, the immunostaining for MST was stronger during the rainy season than during the dry season but the immunostaining for AVT was stronger during the dry season. Abbreviations: $\mathrm{Ax}$ - axone; $\mathrm{Cj}$ - cellular juxtapositions; $\mathrm{Cp}$ - choroid plexus; Ec - ependymal cells; Er — erythrocyte. Scale bars: $20 \mu \mathrm{m}$ for B and $50 \mu \mathrm{m}$ all other.

both males and females, an apical staining sometimes was also observed, particularly in epithelial cells of collector, distal tubules, and neck segment.

In addition, the intensity of $\mathrm{VTR}_{2}$ staining was different according to the seasonal variations. In the dry season the immunostaining in the renal tubes was stronger than that observed during the rainy season (Fig. 6A, B). These observations were valid for all groups. The sections used as negative controls (without primary antibody) were all negative (Fig. 6).

\section{Location of the $A Q P_{2}$ in kidney}

The $\mathrm{AQP}_{2}$, a membrane protein allowing the entry of water after activating the VTR by AVT, was also 


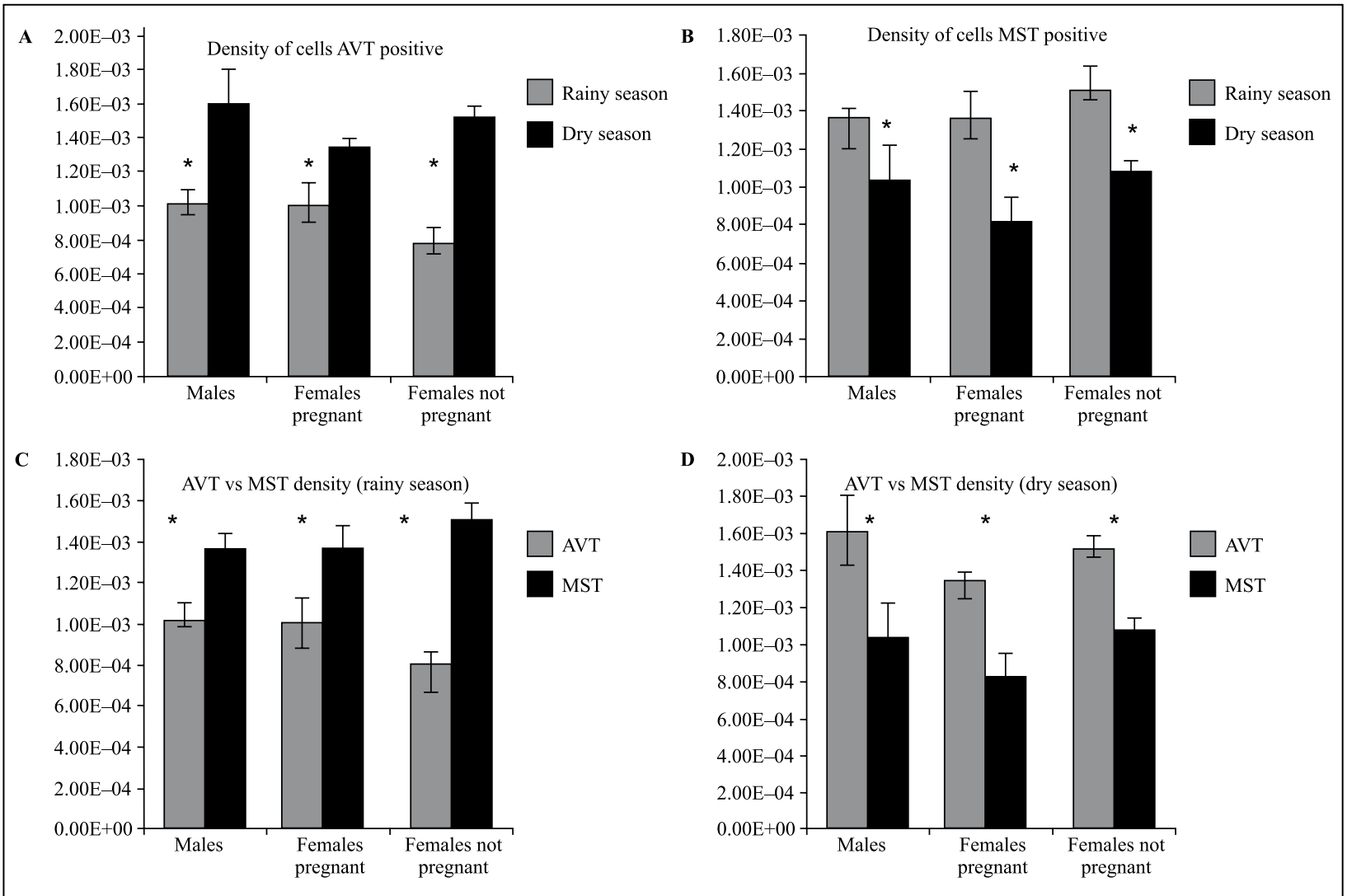

Figure 5. Cell density of MST- and AVT-immunoreactive cells in + T. compressicauda hypothalamus according to the seasonal cycle. The number of MST-positive cells was higher during the rainy season (B), whereas AVT-positive cells were more prevalent during the dry season (A). The effect of season on the proportion of the number of AVT-positive cells to the number of MST-positive cells is presented in panel C (rainy season) and D (dry season). *significant difference ( $\mathrm{p}<0.001$ in all cases).

visualized in kidneys by immunohistochemistry. A red labeling was observed in renal structures in both seasons in males and females. $\mathrm{AQP}_{2}$ labeling showed different intensities throughout renal tubules in the two seasons in males and females, with a higher expression during the dry season (Fig. 6C, D). A membrane staining or apical label sometimes was observed in collecting tubules and other tubes particularly during both the dry and rainy season (Fig. 6E, F). The sections which were incubated with PBS did not present any marking (Fig. 6C, D).

\section{Discussion}

The present study showed the distribution of two hormones (AVT, MST) in the hypothalamus of T. compressicauda with some obvious variations according to the seasons. The two neurohormones were expressed during both seasons in males and females but the labelling intensity of MST was stronger during the rainy season in contrast to AVT. We also localized VTRs and $\mathrm{AQP}_{2}$ in $T$. compressicauda kidney. They were more intensely expressed during the dry season. During the rainy season, the water is abundant and hydromineral exchanges increase. Consequently, the amount of urine increased and contained additional quantity of water. So, the presence of MST (diuretic hormone) and its receptors was particularly necessary for water elimination. On the contrary, during the dry season, the hydromineral exchanges were reduced (less water penetrated into the tissue). Thus, at this season, the antidiuretic role of the AVT was important, increasing the permeability of the collecting tubules. AVT also required the presence of its receptor and consequently, increased the expression of $\mathrm{AQP}_{2}$; which were membrane proteins, facilitating the reabsorption of water in the collection tubules, in response to antidiuretic hormones (AVT, AVP).

Amphibians are associated with alternations between aquatic and terrestrial life and seasonal variations. The variations are different from one species to another according to their environment. Each species has particular mechanisms to maintain its water and electrolyte balance in order to adapt to its own envi- 


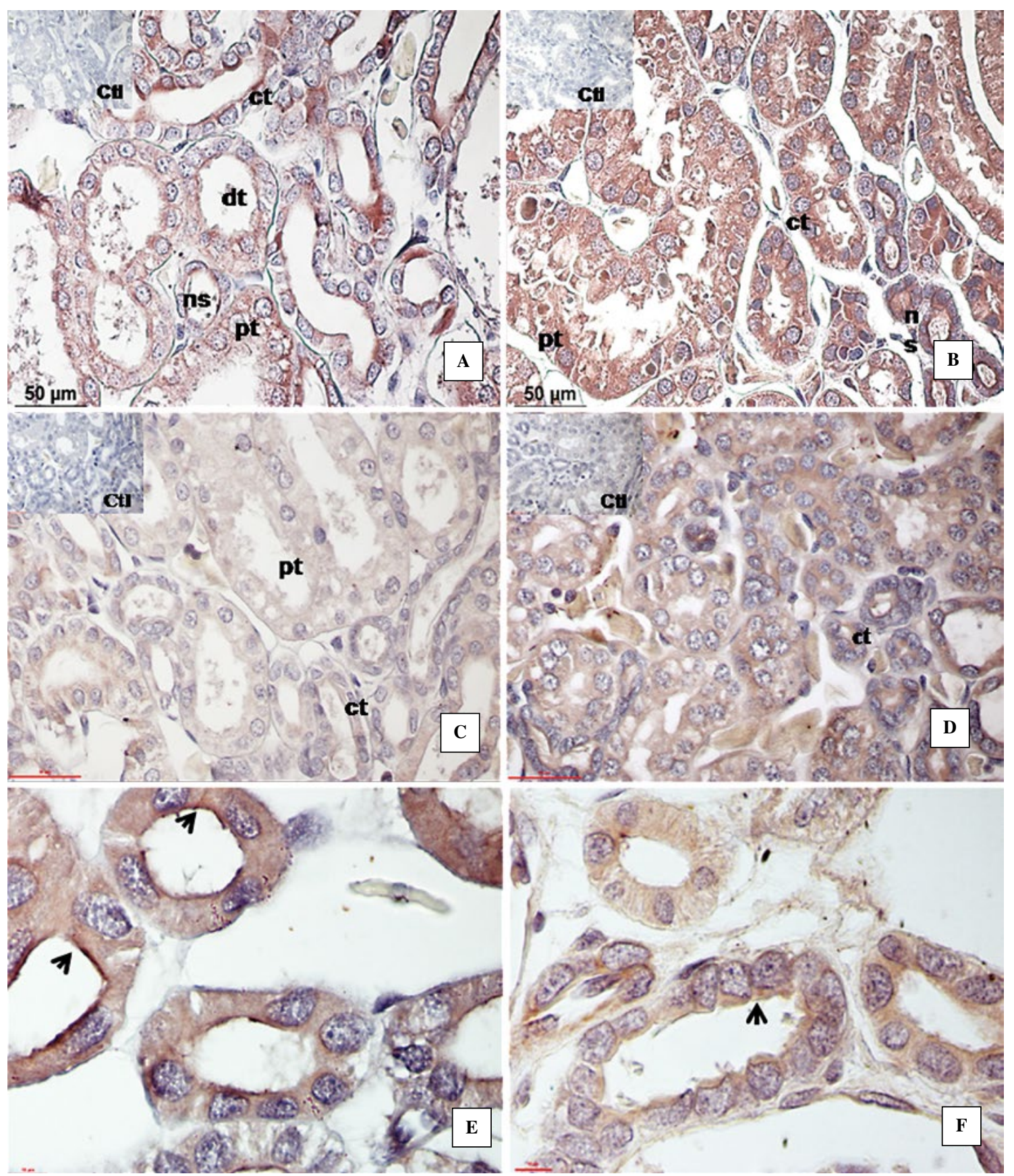

Figure 6. Variations in the expression of vasotocin receptors (VTRs) and aquaporin 2 ( $\mathrm{AQP}_{2}$ ) in kidney of T. compressicauda according to the seasonal cycle. A. VTRs in male during the rainy season. B. VTRs in male during the dry season. C. AQP in male during the rainy season. $\mathbf{D}$. $\mathrm{AQP}_{2}$ in male during the dry season. $\mathbf{E}, \mathbf{F}$. Apical staining of $\mathrm{AQP}_{2}$ in collecting tubule. The intensity of VTR and $\mathrm{AQP}_{2}$ immunoreactivity varied in different kidney structures, however, in all groups the immunostaining was stronger during the dry season than during the rainy season. $\mathrm{AQP}_{2}$ was detected with apical staining especially in collecting tubules during the dry season. Abbreviations: $\mathrm{C}$ - control section stained without primary antibody; ct — colllecting tubule; $\mathrm{dt}$ — distal tubule; ns — neck segment; $\mathrm{pt}$ - proximal tubule. Scale bars: $50 \mu \mathrm{m}$ for A-D, and $20 \mu \mathrm{m}$ for E-F.

ronmental conditions. The hydroosmotic regulation of gymnophiona has been studied by comparing terrestrial species (Ichthyophis) and aquatic species (T. compressicauda) [50, 51]. Wake (1969) reported a larger size and a smaller number of nephrons in the aquatic species Typhlonectes in comparison with terrestrial Gymnopis. Stiffler et al. [51] compared the osmotic exchanges in aquatic Typhlonectes and 
terrestrial Ichthyophis. Their results showed that in the same conditions and after three hours of immersion in natural water, the entry of water was stronger in Ichthyophis than in Typhlonectes. This difference was related to the permeability of the skin, which is higher in terrestrial species, so the rate of glomerular filtration and the water reabsorption were also higher in Ichthyophis. It seems that in T. compressicauda submitted to modifications of the available quantity of water, the hydroosmotic regulation possesses very specific modalities.

Many studies showed that the AVT and MST were involved in hydromineral regulation and other endocrines functions in non-mammalian vertebrates (lungfish, amphibians, reptiles and birds) [12, 18-20]. In amphibian, several hormones regulate the water balance. In addition to MST and AVP also other hormones are involved: prolactin (PRL), aldosterone, corticosterone, and angiotensin II [52]. As mentioned above, AVT and MST perform equivalent functions of AVP and OT in mammals. Previous physiological studies demonstrated the effects of these hormones on water balance in amphibians. The activity of AVT is antidiuretic by increasing the renal tubular water reabsorption and reducing glomerular filtration rate [53-55]. MST stimulates the contractions of smooth muscles, exerts a diuretic effect in amphibians possibly by antagonizing AVT and increasing glomerular filtration rate $[52,56]$. Other works showed that the AVT is a potent stimulator of sexual behaviors and regulates hydromineral balance in the newt Taricha granulosa; it was found that different areas of brain were associated with the hydromineral regulation and sexual behavior such as the optic tectum, ventral infundibular, dorsal preoptic area, and ventral preoptic area nucleus [57].

The presence of AVT/MST was detected in the brain of Rana ridibunda and Pleurodeles waltlii [58], and during the development of Xenopus laevis [59]. Finally, AVT/MST was detected also in T. compressicauda [60]. This study showed that the hypothalamo-hypophysial system of this animal was well developed, with AVT/MST-positive extrahypothalamic cells and an extensive network of nerve fibers. These studies corroborated our results in which MST/AVT was identified in the brain and practically in the hypothalamic area, but in addition, we demonstrated a variation of the labelling intensity and the number of marked cells, depending on seasonal alternations.

The MST and AVT actions are mediated through their receptors. The presence of MTRs/VTRs in $T$. compressicauda kidneys and the variations observed indicate a MST/AVT implication in the hydromineral regulation. Moreover, MTR mRNA and VTR mRNA was detected in kidney, urinary bladder, brain of Hyla japonica [28] and Bufo marinus [21]. The VTR/MTR was characterized in several non-mammalian species [27, 29, 61-63]. These studies support our results in which MTR/VTR was localized in the kidney, with variations of the expression of these receptors according to the seasonal variations in $T$. compressicauda. Several studies were performed in order to test the affinity of receptors with their ligands: AVP/OT. The toad receptor was structurally more related to mammalian OT receptors (OTRs) than to the teleost fish IT receptors (ITRs) [21]. Other study in frog showed that the AVT/MST exhibited a high degree of sequence identity with the mammalian AVP/OT respectively, with higher affinities for the native ligand for each receptor [27]. These results agree with the present immunohistochemical results, which demonstrate the presence of MTR/VTR in kidney of $T$. compressicauda. Furthermore, to prove the specificity of the antibody used, a blocking peptide test was performed.

For the $\mathrm{AQP}_{2}$, our results in T. compressicauda kidney are comparable to those observed by Ogushi et al. [37] who showed the presence of AQP-h2k in the collecting tubules of the frog Hyla japonica. In addition, the AQP2, like AVT, was more intensely expressed during the dry season than during the rainy season. These results can be compared to results obtained in the African Lemniscomys spp., the "striped grass mouse", which exhibits much stronger expression of vasopressin in the dry season than in the rainy season [64]. In T. compressicauda there is a positive correlation between the expression of AVT and AQP2, like it has been shown in H. japonica after treatment with AVT [37]. The level of expression of AQP2 depends on the level of expression of AVT, which corresponds to seasonal variations.

The literature data indicate interactions between the neurohormones MST, AVT, OT, AVP and hormones regulating the sexual cycle. Firstly, in the mammalian counterparts of MST and AVT, it had been shown that OT is able to stimulate prolactin (PRL) released through OTR present on the surface of lactotrophs $[65,66]$. And reciprocally, the PRL stimulates the secretion of OT and AVP in rat [67]. The in vitro production of OT was also increased by luteinizing hormone (LH) in rat [68]. In addition, progesterone can specifically binds to OTR and inhibit the binding of the latter. The administration of estradiol induced an increase of OT plasma concentration $[66,69]$, and stimulated OTR expression in uterus, pituitary gland, and kidney [68, 70]. The same type of interactions was also observed for MST and AVT. A short (30 min) incubation of hypothalamic explants 
of Rana esculenta (Pelophylax kl. esculentus) with AVT or MST increased the production of a number of neurosteroids [26]. Finally, AVT and MST caused uterine contraction in vitro in the immature hen, and ovarian steroids modify the sensitivity to AVT and MST of the chicken uterus [71]. Besides, it was proved that an injection of testosterone caused an elevation of the expression of AVT receptor in chicken pituitary gland [72]. Another study localized the MST/MTR in the epithelial cells of prostate in possum Trichosurus vulpecula with seasonal changes in hormone concentrations immediately before increases and decreases in prostate weight suggestive of a physiological role for MST in prostatic growth and regression [73]. In $T$. compressicauda, the reproductive cycles were linked to seasonal variations, and the reproduction occurring during the rainy season, whereas its preparation required a terrestrial phase, during which animals were buried in the mud. This important step causes changes of the excretory system because the females without dry period have reproductive problems [2].

In summary, our study highlights expression changes of the MST/AVT in the brain, and their receptors MTRs/VTRs, and AQP2 in the kidney of T. compressicauda in relation to the seasonal variations. Our results demonstrated a direct relationship between the seasonal cycle and reproduction cycle in this species. In addition, interactions or direct relationship between the neurohormones involved in the hydromineral regulation and reproductive hormones have been demonstrated in several vertebrates, and this probably occurs in $T$. compressicauda.

\section{Acknowledgements}

We are grateful to Caroline Bouchot, General Biology Laboratory of Catholic University of Lyon technician, for ordering products from suppliers.

\section{References}

1. Wake M. The comparative morphology and evolution of the eyes of caecilians (Amphibia, Gymnophiona). Zoomorphology. 1985; 105(5): 277-295, doi: 10.1007/bf00312059.

2. Exbrayat JM, Laurent MT. Quelques observations sur la reproduction en élevage de deux amphibiens apodes: Typhlonectes compressicaudus et un Ichthyophis. Possibilité de rythmes endog nes. Bulletin de la Société Herpétologique de France. 1986; 40: 52-62.

3. Exbrayat JM. Les Gymnophiones, ces curieux Amphibiens. Paris: Boubée. ; 2000.

4. Wake M. The Spermatogenic Cycle of Dermophis mexicanus (Amphibia: Gymnophiona). Journal of Herpetology. 1995; 29(1): 119, doi: $10.2307 / 1565095$.

5. Exbrayat JM. Premères observations sur le cycle annuel de l'ovaire de Typhlonectes compressicaudus (Duméril et Bibron, 1841), Batracien Apode vivipare. CR Acad Sci. 1983; 296: 493-498.
6. Exbrayat JM, Estabel J. Anatomy with particular reference to the reproductive system. Pp. 79-155. In J.M. Exbrayat (Ed.) Reproductive Biology and Phylogeny of Gymnophiona Caecilians). Science Publishers, U K. 2006; 5: 79-155.

7. Measey GJ, Smitam M, Beyor RS, et al. Year-round spermatogenic activity in an oviparous subterranean Caecilian, Boulengurula taitanus Loveridge 1935 (Amphibia Gymnophiona Caeciliidae). Tropical Zoology. 2008; 21: 109-122.

8. Raquet MA, Measey GJ, Exbrayat JM. Annual variation of ovarian structures ofBoulengerula taitana(Loveridge 1935), a Kenyan caecilian. African Journal of Herpetology. 2015; 64(2): 116-134, doi: 10.1080/21564574.2015.1103787.

9. Moodie G. Observations on the life history of the caecilian Typhlonectes compressicaudus (Dumeril and Bibron) in the Amazon basin. Canadian Journal of Zoology. 1978; 56(4): 1005-1008, doi: 10.1139/z78-141.

10. Exbrayat JM, Delsol M, Flatin J. Typhlonectes compressicaudus Amphibien vivipare de Guyane. Le Littoral Guyanais, Fragilité de l'Environnement. Nature Guyanaise. 1er congrès régional SEPANGUY, 10éme coll. SEPANRI. Edited by SEPANGUY, Cayenne, SEPANRIT, Bordeaux.; 1986: 119-124.

11. Exbrayat JM, Morel G. Prolactin (PRL)-coding mRNA in Typhlonectes compressicaudus, a viviparous gymnophionan amphibian: an in situ hybridization study. Cell and Tissue Research. 1995; 280(1): 133-138, doi: 10.1007/bf00304518.

12. Acher R. Chemistry of the neurohypophysial hormones: an example of molecular evolution. Handbook of physiology. 1974; 4: 119-130.

13. Oksche A. The neuroanatomical basis of comparative neuroendocrinology. Gen Comp Endocrinol. 1976; 29(2): 225-239, indexed in Pubmed: 955383.

14. Dierickx K. Immunocytochemical localization of the vertebrate cyclic nonapeptide neurohypophyseal hormones and neurophysins. Int Rev Cytol. 1980; 62: 119-185, indexed in Pubmed: 6988359.

15. Acher R, Chauvet J. The neurohypophysial endocrine regulatory cascade: precursors, mediators, receptors, and effectors. Front Neuroendocrinol. 1995; 16(3): 237-289, doi: 10.1006/ /frne.1995.1009, indexed in Pubmed: 7556852.

16. Moore FL, Lowry CA. Comparative neuroanatomy of vasotocin and vasopressin in amphibians and other vertebrates. Comp Biochem Physiol C Pharmacol Toxicol Endocrinol. 1998; 119(3): 251-260, indexed in Pubmed: 9826998.

17. Acher R. Neurohypophysial peptide systems: processing machinery, hydroosmotic regulation, adaptation and evolution. Regul Pept. 1993; 45(1-2): 1-13, indexed in Pubmed: 8511331.

18. Dantzler WH, Braun EJ. Comparative nephron function in reptiles, birds, and mammals. Am J Physiol. 1980; 239(3): R197-R213, doi: 10.1152/ajpregu.1980.239.3.R197, indexed in Pubmed: 7001920.

19. Rice GE. Plasma arginine vasotocin concentrations in the lizard Varanus gouldii (Gray) following water loading, salt loading, and dehydration. Gen Comp Endocrinol. 1982; 47(1): 1-6, indexed in Pubmed: 7084654.

20. Takei Y. Comparative physiology of body fluid regulation in vertebrates with special reference to thirst regulation. Jpn J Physiol. 2000; 50(2): 171-186, indexed in Pubmed: 10880873.

21. Akhundova A, Getmanova E, Gorbulev V, et al. Cloning and functional characterization of the amphibian mesotocin receptor, a member of the oxytocin/vasopressin receptor superfamily. Eur J Biochem. 1996; 237(3): 759-767, indexed in Pubmed: 8647123. 
22. Zardoya R. Phylogeny and evolution of the major intrinsic protein family. Biol Cell. 2005; 97(6): 397-414, doi: 10.1042/ /BC20040134, indexed in Pubmed: 15850454.

23. Fu D, Lu M. The structural basis of water permeation and proton exclusion in aquaporins. Mol Membr Biol. 2007; 24(5-6): 366-374, doi: 10.1080/09687680701446965, indexed in Pubmed: 17710641.

24. Boyd SK. Arginine vasotocin facilitation of advertisement calling and call phonotaxis in bullfrogs. Horm Behav. 1994; 28(3): 232-240, doi: 10.1006/hbeh.1994.1020, indexed in Pubmed: 7814004

25. Goodson JL, Bass AH. Social behavior functions and related anatomical characteristics of vasotocin/vasopressin systems in vertebrates. Brain Res Brain Res Rev. 2001; 35(3): 246-265, indexed in Pubmed: 11423156.

26. Do-Rego JL, Acharjee S, Seong JY, et al. Vasotocin and mesotocin stimulate the biosynthesis of neurosteroids in the frog brain. J Neurosci. 2006; 26(25): 6749-6760, doi: 10.1523/ /JNEUROSCI.4469-05.2006, indexed in Pubmed: 16793882.

27. Acharjee S, Do-Rego JL, Oh DY, et al. Identification of amino acid residues that direct differential ligand selectivity of mammalian and nonmammalian V1a type receptors for arginine vasopressin and vasotocin. Insights into molecular coevolution of V1a type receptors and their ligands. J Biol Chem. 2004; 279(52): 54445-54453, doi: 10.1074/jbc.M408909200, indexed in Pubmed: 15475353.

28. Kohno S, Kamishima Y, Iguchi T. Molecular cloning of an anuran $\mathrm{V}(2)$ type $[\operatorname{Arg}(8)]$ vasotocin receptor and mesotocin receptor: functional characterization and tissue expression in the Japanese tree frog (Hyla japonica). Gen Comp Endocrinol. 2003; 132(3): 485-498, indexed in Pubmed: 12849972.

29. Acharjee S. Molecular cloning, pharmacological characterization, and histochemical distribution of frog vasotocin and mesotocin receptors. Journal of Molecular Endocrinology. 2004; 33(1): 293-313, doi: 10.1677/jme.0.0330293.

30. Bentley PJ. Endocrines and osmoregulation: a comparative account in vertebrates. Springer Science \& Business Media. ;2002.

31. Bentley AJ, Yorio T. Do Frogs Drinks? Journal of Experimental Biology. 1979; 79(1): 41-46.

32. Hillyard SD. Behavioral, molecular and integrative mechanisms of amphibian osmoregulation. J Exp Zool. 1999; 283(7): 662-674, indexed in Pubmed: 10222590.

33. Uchiyama M, Konno N. Hormonal regulation of ion and water transport in anuran amphibians. Gen Comp Endocrinol. 2006; 147(1): 54-61, doi: 10.1016/j.ygcen.2005.12.018, indexed in Pubmed: 16472810.

34. Suzuki M, Tanaka S. Molecular diversity of vasotocin-dependent aquaporins closely associated with water adaptation strategy in anuran amphibians. J Neuroendocrinol. 2010; 22(5): 407-412, doi: 10.1111/j.1365-2826.2010.01981.x, indexed in Pubmed: 20163517.

35. Tanii H, Hasegawa T, Hirakawa N, et al. Molecular and cellular characterization of a water-channel protein, AQP-h3, specifically expressed in the frog ventral skin. J Membr Biol. 2002; 188(1): 43-53, doi: 10.1007/s00232-001-0172-4, indexed in Pubmed: 12172646.

36. Tanaka S, Hasegawa $\mathrm{T}$, Tanii $\mathrm{H}$, et al. Immunocytochemical and phylogenetic distribution of aquaporins in the frog ventral skin and urinary bladder. Ann N Y Acad Sci. 2005; 1040: 483-485, doi: 10.1196/annals.1327.097, indexed in $\mathrm{Pu}-$ bmed: 15891096.

37. Ogushi Y, Mochida H, Nakakura T, et al. Immunocytochemical and phylogenetic analyses of an arginine vasotocin-dependent aquaporin, AQP-h2K, specifically expressed in the kidney of the tree frog, Hyla japonica. Endocrinology. 2007; 148(12): 5891-5901, doi: 10.1210/en.2007-0613, indexed in Pubmed: 17872371.

38. Sasaki S, Noda Y. Aquaporin-2 protein dynamics within the cell. Curr Opin Nephrol Hypertens. 2007; 16(4): 348-352, doi: 10.1097/MNH.0b013e32818b27bf, indexed in Pubmed: 17565277.

39. Wake, M.H. Evolutionary morphology of the caecilian urogenital system. Part II: the kidneys and urogenital ducts. Acta Anatomica. 1970; 75: 321-358.

40. Sakai T, Billo R, Kriz W. The structural organization of the kidney of Typhlonectes compressicaudus (Amphibia, Gymnophiona). Anat Embryol (Berl). 1986; 174(2): 243-252, indexed in Pubmed: 3740458.

41. Sakai T, Billo R, Nobiling R, et al. Ultrastructure of the kidney of a South American caecilian, Typhlonectes compressicaudus (Amphibia, Gymnophiona). Cell Tissue Res. 1988; 252(3): 589-600, doi: 10.1007/bf00216646.

42. Sakai T, Billo R, Kriz W. Ultrastructure of the kidney of a South American caecilian, Typhlonectes compressicaudus (Amphibia, Gymnophiona). II. Distal tubule, connecting tubule, collecting duct and Wolffian duct. Cell Tissue Res. 1988; 252(3): 601-610, indexed in Pubmed: 3396058.

43. Korte GE, Rosenbluth J. Ependymal astrocytes in the frog cerebellum. Anat Rec. 1981; 199(2): 267-279, doi: 10.1002/ ar.1091990211, indexed in Pubmed: 6971063.

44. Leclercq B. Martin- Bouyer L, Exbrayat JM. Embryonic development of pineal organ in Typhlonectes compressicauda, a viviparous Gymnophionan Amphibia. Scientia Herpetologica. 1995; 1995: 107-111.

45. Clairambault $\mathrm{P}, \mathrm{Christophe} \mathrm{N}$, Pairault $\mathrm{C}$, et al. Organization of the serotoninergic system in the brain of two amphibian species, Ambystoma mexicanum (Urodela) and Typhlonectes compressicauda (Gymnophiona). Anat Embryol (Berl). 1994; 190(1): 87-99, indexed in Pubmed: 7985815.

46. Estabel J, Exbrayat JM. Brain development of Typhlonectes compressicaudus. Journal of herpetology. ; 1998: 1-10, doi: $10.2307 / 1565472$

47. Exbrayat JM. The cytological modifications of the distal lobe of the hypophysis in Typhlonectes compressicaudus (Duméril and Bibron, 1841), amphibian gymnophiona, during the cycles of seasonal activity. I: In adult males. Archives d'anatomie microscopique et de morphologie expérimentale. 1989; 2(4): 117-123.

48. Exbrayat JM, Morel G. The cytological modifications of the distal lobe of the hypophysis in Typhlonectes compressicaudus (Dumeril and Bibron, 1841), amphibia gymnophiona, during the cycles of seasonal activity. II: In adult females. Biological structures and morphogenesis. 1990; 3(4): 129-138.

49. Estabel J, Exbrayat JM. Brain Development of Typhlonectes compressicaudus. Journal of Herpetology. 1998; 32(1): 1, doi: $10.2307 / 1565472$.

50. Wake WH. Kidney morphology in terrestrial and aquatic caecilians. Anat Rec. 1969; 163(2): 331.

51. Stiffler D, DeRuyter M, Talbot C. Osmotic and Ionic Regulation in the Aquatic Caecilian Typhlonectes compressicauda and the Terrestrial Caecilian Ichthyophis kohtaoensis. Physiological Zoology. 1990; 63(4): 649-668, doi: 10.1086/ /physzool.63.4.30158168.

52. Warburg MR. Hormonal effect on the osmotic, electrolyte and nitrogen balance in terrestrial Amphibia. Zoolog Sci. 1995; 12(1): 1-11, doi: 10.2108/zsj.12.1, indexed in Pubmed: 7795483.

53. Eggena P, Schwartz IL, Walter R. A sensitive hydroosmotic toad bladder assay. Affinity and intrinsic activity of neuro- 
hypophyseal peptides. J Gen Physiol. 1968; 52(3): 465-481, indexed in Pubmed: 5691711.

54. Shoemaker V, Bickler P. Kidney and bladder function in a uricotelic treefrog (Phyllomedusa sauvagei). J Comp Physiol B. 1979; 133(3): 211-218, doi: 10.1007/bf00691468.

55. Yorio T, Bentley PJ. Asymmetrical permeability of the integument of tree frogs (Hylidae). J Exp Biol. 1977; 67: 197-204, indexed in Pubmed: 894178.

56. Pang PK, Sawyer WH. Renal and vascular responses of the bullfrog (Rana catesbeiana) to mesotocin. Am J Physiol. 1978; 235(2): F151-F155, doi: 10.1152/ajprenal.1978.235.2.f151, indexed in Pubmed: 308323.

57. Zoeller RT, Moore FL. Brain arginine vasotocin concentrations related to sexual behaviors and hydromineral balance in an amphibian. Horm Behav. 1988; 22(1): 66-75, indexed in Pubmed: 3350478.

58. González A, Smeets WJ. Comparative analysis of the vasotocinergic and mesotocinergic cells and fibers in the brain of two amphibians, the anuran Rana ridibunda and the urodele Pleurodeles waltlii. J Comp Neurol. 1992; 315(1): 53-73, doi: 10.1002/cne.903150105, indexed in Pubmed: 1541723.

59. González A, Mun oz A, Mun oz M, et al. Ontogeny of vasotocinergic and mesotocinergic systems in the brain of the South African clawed frog Xenopus laevis. J Chem Neuroanat. 1995; 9(1): 27-40, doi: 10.1016/0891-0618(95)00063-d.

60. González A, Smeets W. Distribution of vasotocin- and mesotocin-like immunoreactivities in the brain of Typhlonectes compressicauda (Amphibia, Gymnophiona): further assessment of primitive and derived traits of amphibian neuropeptidergic systems. Cell Tissue Res. 1997; 287(2): 305-314, doi: 10.1007/s004410050755.

61. Mahlmann S, Meyerhof W, Hausmann H, et al. Structure, function, and phylogeny of [Arg8]vasotocin receptors from teleost fish and toad. Proc Natl Acad Sci U S A. 1994; 91(4): 1342-1345, indexed in Pubmed: 7509069.

62. Takahashi T, Kawashima M, Yasuoka T, et al. Mesotocin receptor binding of cortical and medullary kidney tissues of the hen. Poult Sci. 1997; 76(9): 1302-1306, doi: 10.1093/ /ps/76.9.1302, indexed in Pubmed: 9276895.

63. Warne JM. Cloning and characterization of an arginine vasotocin receptor from the euryhaline flounder Platichthys flesus. Gen Comp Endocrinol. 2001; 122(3): 312-319, doi: 10.1006/ /gcen.2001.7644, indexed in Pubmed: 11356043.
64. Schoepf I, Schradin C. Arginine vasopressin plasma levels change seasonally in African striped mice but do not differ between alternative reproductive tactics. Gen Comp Endocrinol. 2014; 204: 43-48, doi: 10.1016/j.ygcen.2014.05.002, indexed in Pubmed: 24842715.

65. Lumpkin MD, Samson WK, McCann SM. Hypothalamic and pituitary sites of action of oxytocin to alter prolactin secretion in the rat. Endocrinology. 1983; 112(5): 1711-1717, doi: 10.1210/endo-112-5-1711, indexed in Pubmed: 6403333.

66. Kennett JE, McKee DT. Oxytocin: an emerging regulator of prolactin secretion in the female rat. J Neuroendocrinol. 2012; 24(3): 403-412, doi: 10.1111/j.1365-2826.2011.02263.x, indexed in Pubmed: 22129099.

67. Vega C, Moreno-Carranza B, Zamorano M, et al. Prolactin promotes oxytocin and vasopressin release by activating neuronal nitric oxide synthase in the supraoptic and paraventricular nuclei. Am J Physiol Regul Integr Comp Physiol. 2010; 299(6): R1701-R1708, doi: 10.1152/ajpregu.00575.2010, indexed in Pubmed: 20943859.

68. Gimpl G, Fahrenholz F. The oxytocin receptor system: structure, function, and regulation. Physiol Rev. 2001; 81(2): 629-683, doi: 10.1152/physrev.2001.81.2.629, indexed in Pubmed: 11274341.

69. Zingg HH, Grazzini E, Breton C, et al. Genomic and non-genomic mechanisms of oxytocin receptor regulation. Adv Exp Med Biol. 1998; 449: 287-295, indexed in Pubmed: 10026816.

70. Zingg HH, Laporte SA. Laporte SA. The oxytocin receptor Trends Endocrinology Metabolis 2003; 14: 222-227, doi: 10 1016/S1043. 2760; 03: 00080-8, doi: 10.1016/S10432760.

71. Rzasa J, Ewy Z. The effect of ovarian steroids on the response of the hen uterus to neurohypophysial hormones. Acta Physiol Pol. 1982; 33(4): 249-255, indexed in Pubmed: 7184310.

72. Sharma $\mathrm{D}$, Chaturvedi CM. Testosterone modulates pituitary vasotocin receptor expression and adrenal activity in osmotically stressed chicken. Comp Biochem Physiol A Mol Integr Physiol. 2011; 158(1): 87-93, doi: 10.1016/j.cbpa.2010.09.008, indexed in Pubmed: 20850559.

73. Fink JoW, McLeod BJ, Assinder SJ, et al. Seasonal changes in mesotocin and localization of its receptor in the prostate of the brushtail possum (Trichosurus vulpecula). Biol Reprod. 2005; 72(2): 470-478, doi: 10.1095/biolreprod.104.035006, indexed in Pubmed: 15496513.

Submitted: 16 November, 2016

Accepted after reviews: 24 July, 2018

Available as AoP: 31 July, 2018 
